\title{
Pengaruh Model Pembelajaran Science Reflective Journal Writing terhadap Hasil Belajar Fisika Pada Siswa Kelas VIII SMP Negeri 9 Palu
}

\author{
Arwiyah, I Komang Werdhiana dan Muslimin \\ email:awiwi18@gmail.com \\ Program Studi Pendidikan Fisika FKIP Universitas Tadulako \\ Jl. Soekarno Hatta Km. 9 Kampus Bumi Tadulako Tondo Palu - Sulawesi Tengah
}

\begin{abstract}
Abstrak - Penelitian ini bertujuan untuk mengetahui ada tidaknya pengaruh model Pembelajaran Science Reflective Journal Writing terhadap hasil belajar fisika siswa pada kelas VIII SMP Negeri 9 Palu. Metode yang digunakan adalah metode quasi eksperimen dengan The nonequivalent pretest-posttest group design. Penelitian dilaksanakan pada siswa kelas VIII SMP Negeri 9 Palu. Teknik pengambilan sampel adalah purposive sampling. Kelas VIII A sebagai kelas eksperimen dan kelas VIII B sebagai kelas kontrol. Instrumen berupa tes pilihan ganda yang telah diuji validitas dan reliabilitasnya. Hipotesis yang diajukan adalah ada pengaruh model pembelajaran science reflective journal writing terhadap hasil belajar fisika pada siswa kelas VIII SMP Negeri 9 Palu. Pengujian Hipotesis menggunakan uji-t satu pihak dengan taraf nyata $\alpha=0,05$ dan $\mathrm{dk}=48$, dengan uji prasyarat normalitas dan homogenitas. Hasil penelitian ini menunjukkan bahwa model pembelajaran science reflective journal writing berpengaruh terhadap hasil belajar fisika siswa.
\end{abstract}

Kata kunci: Science Reflective Journal Writing, Hasil Belajar

\section{PENDAHULUAN}

Tujuan dari pembelajaran setidak-tidaknya seorang guru menanamkan tiga domain, yakni kognitif, afektif dan psikomotor dan ketiga domian itu secara langsung akan tertanam pada setiap siswa yang mengikuti suatu proses pembelajaran. Oleh karena itu, yang paling mendasar dipahami oleh guru adalah melatih siswa untuk berpikir, memecahkan masalah dan menemukan sesuatu yang baru.

Penerapan model pembelajaran yang digunakan guru sangat menentukan suatu keberhasilan dalam proses pembelajaran. Menurut Wenning [1] dengan penggunaan model pembelajaran yang tepat dapat meningkatkan hasil belajar siswa. Hasil belajar akan dicapai dengan baik apabila proses pembelajaran berjalan dengan baik pula. Oleh sebab itu sebagai seorang guru yang baik diharapkan dapat menciptakan suasana dan lingkungan belajar yang efektif, sehingga tujuan pembelajaran akan optimal.

Keterampilan menulis memberikan manfaat yang sangat berguna bagi siswa, yaitu: untuk mengembangkan kepribadian, memperluas wawasan, mengembangkan kreativitas, menanamkan keberanian dan percaya diri, dan membantu siswa menuangkan ide, pikiran, pengalaman, perasaan dan cara memandang kehidupan [2]. Para guru dapat menggunakan kegiatan menulis untuk memperoleh umpan balik (feedback) atas pengajarannya di kelas.

Science reflective journal writing (SRJ) adalah kebiasaan yang dipraktikan guru-guru di Inggris untuk menginterprestasikan sebuah kejadian, menghubungkan kejadian-kejadian dengan tahap konsepsi awal dan dampaknya terhadap pengajaran di masa mendatang. Model pembelajaran Science reflective journal writing merupakan model pembelajaran yang menekankan pada penulisan jurnal pada setiap akhir pembelajaran dan merefleksikan kembali pada pembelajaran mendatang.

Menurut Towndrow et al [3], tahapan proses pembelajaran science reflective journal writing adalah sebagai berikut; Tahapan pertama, guru menghadirkan satu atau dua pertanyaan yang menarik di dalam kelas. Tahapan selanjutnya, guru membimbing siswa untuk dapat mengeksplorasi pertanyaan yang diberikan tadi dengan sesama teman atau mencari referensi dari sumber-sumber lain yang disarankan guru. Kemudian guru mengajarkan materi selanjutnya di dalam kelas. Tahapan akhir, setiap akhir pembelajaran siswa dibimbing untuk menulis refleksi di dalam SRJ mereka. Pada akhir pekan guru mengumpulkan SRJ untuk dibaca. Kemudian kembali lagi kepada tahap pertama. 
Beberapa hasil penelitian telah menunjukkan bahwa model pembelajaran science reflective journal writing dapat meningkatkan hasil belajar fisika siswa. Penelitian yang dilakukan oleh Yudi (4) menunjukan bahwa pembelajaran dengan menggunakan strategi scince reflective journal writing (SRJ) dapat meningkatkan prestasi belajar siswa Begitu pula penelitian Towndrow et al (2008), ternyata berhasil meningkatkan kemampuan bertanya siswa pada proses pembelajaran yang dilakukan. Hal ini terlihat karena semakin berkualitas pertanyaanpertanyaan yang diajukan siswa dari waktu ke waktu. Dan penelitian yang dilakukan Ana Fadllia (5), pembuatan jurnal belajar dalam pendekatan Jelajah Alam Sekitar (JAS) ternyata dapat meningkatkan hasil belajar siswa baik secara ranah kognitif, afektif maupun psikomotorik.

Hasil observasi pada proses belajar fisika di SMP Negeri 9 Palu sering terjadi keluhan. Siswa merasa bahwa pelajaran fisika merupakan mata pelajaran yang sulit dan membosankan sehingga daya serap siswa terhadap pelajaran fisika kurang baik. Kondisi yang membosankan akan menurunkan bahkan menghilangkan motivasi siswa. Selain itu kurangnya kerjasama dan komunikasi antara siswa dalam proses belajar mengajar juga merupakan salah satu penyebab rendahnya hasil belajar siswa.

Salah satu upaya untuk memecahkan masalah rendahnya aktivitas siswa yang berakibat pada rendahnya hasil belajar fisika pada siswa kelas VIII SMP Negeri 9 Palu adalah dengan menerapkan model pembelajaran scince reflective journal writing (SRJ). Oleh sebab itu, pada penelitian ini dipaparkan "Pengaruh Model Pembelajaran Scince Reflective Journal Writing (SRJ) Terhadap Hasil Belajar Fisika Pada Siswa Kelas VIII SMP Negeri 9 Palu".

\section{METODE PENELITIAN}

Jenis penelitian yang digunakan dalam penelitian ini adalah eksperimen kuasi dengan pola the nonequivalent pretest-posttest control group design (tes awal-tes akhir yang tidak ekuivalen). Adapun desainnya menurut Sugiyono (6) pada Tabel 1.

Tabel 1 Desain Penelitian

\begin{tabular}{|l|c|c|c|}
\hline Kelas & $\begin{array}{c}\text { Tes } \\
\text { Awal }\end{array}$ & Perlakuan & $\begin{array}{c}\text { Tes } \\
\text { Akhir }\end{array}$ \\
\hline Eksperimen & $\mathrm{O}_{1}$ & $\mathrm{X}$ & $\mathrm{O}_{2}$ \\
\hline Kontrol & $\mathrm{O}_{1}$ & & $\mathrm{O}_{2}$ \\
\hline
\end{tabular}

Keterangan:

$\mathrm{O}_{1}=$ Tes awal
$\mathrm{O}_{2}=$ Tes akhir

$\mathrm{X}=$ Perlakuan

pembelajaran

writing (SRJ).

Populasi dari penelitian ini adalah seluruh siswa kelas VIII SMPN 9 Palu semester ganjil tahun ajaran 2014/2015 yang tersebar dalam 10 kelas. Sampel pada penelitian ini dipilih 2 kelas yaitu kelas VIII A sebagai kelas eksperimen dan kelas VIII B sebagai kelas kontrol. Teknik pengampilan sampel dengan purposive sampling. Teknik yang digunakan dalam pengumpulan data adalah pemberian tes berupa soal pilihan ganda yang berjumlah 15 nomor.

Instrumen yang digunakan divalidasi ahli terlebih dahulu sebelum diujicobakan dan digunakan untuk penelitian. Validitas yang digunakan adalah validitas isi dan konstruksi. Pengujian hipotesis menggunakan uji-t satu pihak (1-tailed). Dengan kriteria pengujian: Jika $t_{\text {hitung }}>t_{\text {tabel }}$ berarti $\mathrm{H}_{1}$ diterima dan Jika $t_{\text {hitung }}$ $<t_{\text {tabel }}$ berarti $\mathrm{H}_{1}$ ditolak.

III. HASIL DAN PEMBAHASAN

Deskripsi perolehan skor rata-rata hasil belajar tes awal dan tes akhir kelompok eksperimen dan kontrol dapat dilihat pada Gambar 1.

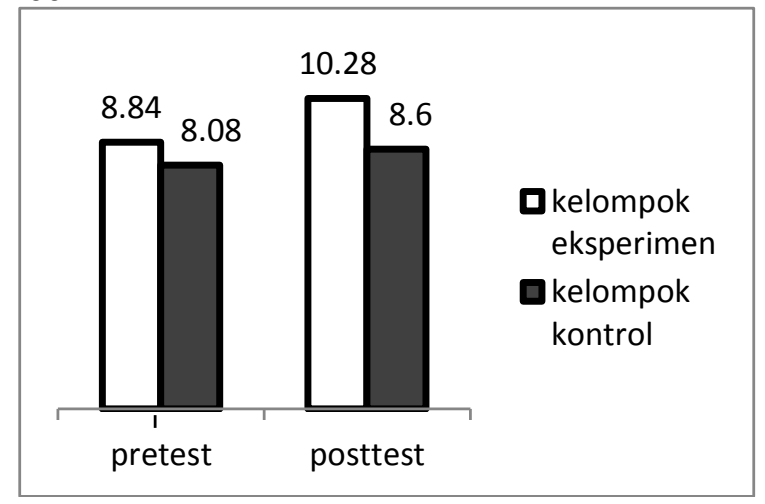

Gambar 1 Perbandingan Skor Rata-Rata Hasil

Belajar tes awal dan tes akhir Kelompok Eksperimen dan Kontrol

Analisis data tes akhir untuk menentukan apakah terdapat pengaruh model pembelajaran science reflective journal writing (SRJ) terhadap hasil belajar fisika. Pada pengujian normalitas data kelas kontrol dan eksperimen diperoleh bahwa kedua data berdistribusi normal. Hasil uji homogenitas pada kedua data adalah varians kedua kelompok homogen. Pada uji hipotesis diperoleh bahwa $t$ hit $>t$ tab sehingga hipotesis $\mathrm{H}_{1}$ 
diterima dan $\mathrm{H}_{0}$ ditolak. Artinya terdapat pengaruh model pembelajaran science reflective journal writing (SRJ) terhadap hasil belajar siswa kelas VIII SMP Negeri 9 Palu.

Siswa pada kelas eksperimen memiliki nilai rata-rata lebih tinggi dibandingkan siswa pada kelas kontrol. Hal ini didukung oleh keunggulan model pembelajaran science reflective journal writing (SRJ) yang dilihat peneliti saat melakukan penelitian diantaranya seluruh siswa dapat menguasai materi yang diajarkan dengan pemahaman konsep yang lebih baik dibandingkan dengan model pembelajaran langsung, para siswa juga terlihat antusias saat proses pembelajaran berlangsung sehingga kelas menjadi lebih hidup dan guru tidak terkesan monoton dalam proses belajar mengajar.

Hal ini relevan dengan beberapa hasil penelitian yang menggunakan model pembelajaran science reflective journal writing dapat meningkatkan hasil belajar fisika siswa baik secara ranah kognitif, afektif maupun psikomotorik. Selain itu, siswa kelas eksperimen memiliki nilai rata-rata dan ketuntasan belajar lebih tinggi dari kelas kontrol.

Penulisan jurnal dimaksudkan agar siswa lebih aktif dalam proses pembelajaran. Menulis jurnal membantu siswa untuk mengasah keterampilan berbahasa siswa yang dipergunakan untuk berkomunikasi secara tidak langsung, tidak secara tatap muka dengan orang lain. Guru menggunakan kegiatan menulis untuk memperoleh umpan balik (feedback) atas hasil pengajarannya di kelas. Refleksi adalah sebuah kegiatan yang dilakukan dalam proses belajar mengajar berupa penilaian tertulis oleh siswa kepada guru, berisi ungkapan kesan, pesan, harapan serta kritik membangun atas pembelajaran yang diterimanya. Guru menggunakan kegiatan refleksi sebagai bahan observasi untuk mengetahui sejauh mana tujuan pembelajaran itu tercapai. Selain itu, melalui kegiatan ini dapat tercapai kepuasan dalam diri siswa yaitu memperoleh wadah yang tepat dalam menjalin komunikasi positif dengan guru. Reflective journal writing adalah kegiatan untuk menginterprestasikan sebuah kejadian, menghubungkan kejadian-kejadian dengan tahap konsepsi awal dan dampaknya terhadap pengajaran di masa mendatang. Satu dari kemampuan inti teridentifikasi disini adalah mengidentifikasi dan mengajukan pertanyaan. Dan ini merupakan kemampuan spesifik yang dibangun oleh science reflective journal writing
ISSN 23383240

(SRJ) juga memungkinkan siswa untuk dapat mengidentifikasi dan merekam apa yang telah mereka pelajari dan bagaimana sikap mereka saat pembelajaran.

Selain keunggulan tersebut, menggunakan model pembelajaran scince reflective journal writing (SRJ) juga tidaklah mudah. Standar penilaian tiap anak berbeda atau penilaian bersifat individualis, beberapa hal yang juga menghambat peneliti saat proses penelitian yaitu efisiensi waktu yang sangat perlu diperhatikan sebab model pembelajaran ini banyak menyita waktu dan juga kesiapan diri (guru) yang harus sangat matang untuk menjadi fasilitator maupun motivator yang baik.

\section{KESIMPULAN}

Berdasarkan hasil penelitian dan analisis data disimpulkan bahwa ada pengaruh model pembelajaran science reflective journal writing (SRJ) terhadap hasil belajar fisika pada siswa kelas VIII SMP Negeri 9 Palu. Berdasarkan uji statistik diperoleh harga $t$ hit $=2,46$ dan berdasarkan daftar tabel distribusi $t$ diperoleh harga $t$ tabel $=1,68$. Hasil uji hipotesis memperlihatkan bahwa harga $t$ hit $>t_{\text {tab }}$ sehingga $\mathrm{H} 1$ diterima pada taraf nyata $\mathrm{a}=0,05$.

\section{DAFTAR PUSTAKA}

[1] MK, Fatmawati. (2007). Perbedaan Hasil Belajar Fisika antara Metode Kawakito Jiro dengan Metode Think Pair Share pada Siswa Kelas X MAN Model Palu. Skripsi Tidak Dipublikasikan. Palu:FKIP UNTAD.

[2] Sutrisna. (2012). Tujuan dan manfaat menulis. [Online]. Tersedia:http://bahasakublog.wordpress. com/2012/08/13/ tujauan dan manfaat menulis. [30 Agustus 2013].

[3] Towndrow, PA. (2008). Promoting Inquiry Through Science Reflective Journal Writing. Nanyang Technological University: Singapore. [Online]. Tersedia: (www.ejmste.com/v4n3/EURASIA v4n3 Towndrow.pdf

[4] Yudi. (2007). Model Pembelajaran Inkuiri dengan Strategi Science Reflective Journal Writing dan Prestasi Belajar. Skripsi Tidak Dipublikasikan. Bandung: Universitas Pendidikan Indonesia. 
[5] Fadlia, Ana. 2012. Pengaruh Pembuatan Jurnal belajar dalam Pendekatan Jelajah Alam Sekitar (JAS) terhadap Hasil Belajar Siswa pada Materi Ekosistem di SMA Negeri 1 Kaliwungu. [Online]. Tersedia:lib.unnes.ac.id/18849/1/440140 8054.pdf.

[6] Sugiyono.(2010).Metode Penelitian Pendidikan. Bandung: PT. Alfabeta.

[7] Arikunto, Suharsimi. 2008. Dasar-dasar Evaluasi Pendidikan (Edisi Revisi). Jakarta: PT. Bumi Aksara. 